\title{
Is electromagnetic guidance system superior to a free-hand technique for distal locking in intramedullary nailing of tibial fractures? A prospective comparative study
}

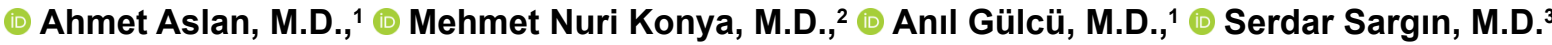 \\ 1'Department of Orthopedics and Traumatology, Alanya Alaaddin Keykubat University Faculty of Medicine, Antalya-Turkey \\ 2Department of Orthopedics and Traumatology, Afyon Health Science University Faculty of Medicine, Afyonkarahisar-Turkey \\ ${ }^{3}$ Department of Orthopedics and Traumatology, Balikesir University Faculty of Medicine, Balikesir-Turkey
}

\begin{abstract}
BACKGROUND: Intramedullary nailing (IMN) technique is the gold standard for the treatment of closed fractures of the lower extremity long bones. For orthopedic surgeons, one of the most important problems in IMN procedures is the fixation of distal locking screws (DLS). Accurate and rapid placement of DLSs with minimal radiation exposure is crucial. In this study, we aimed to compare the results of two different distal locking methods concerning surgery duration and radiation exposure in patients who underwent osteosynthesis of tibia fractures with IMN.

METHODS: In this prospective study, the results of 56 patients who met the inclusion and exclusion criteria from 72 patients were evaluated. Patients were divided into two groups according to the distal screwing method. Group I ( $\mathrm{n}=29$ ) comprised patients who used free-hand technique (FHT) for distal locking, while Group $2(n=27)$ consisted of patients who used electromagnetic guidance system (EMGS) for distal locking. Demographic and medical data of the patients, duration of surgery time, amount of bleeding, total fluoroscopy counts, the time elapsed for distal locking, the measure of radiation exposure, number of attempts for distal screw locking, incorrect screw placements, complications and follow-up time were recorded. The groups were compared concerning demographic data and clinical results.
\end{abstract}

RESULTS: There was no statistically significant difference between the groups about gender and side $(p=0.928$ and $p=0.432$, respectively). The mean age in Group-I was higher than that of Group-2, and the difference was statistically significant $(p=0.012)$. However, there was no statistically significant difference in length of hospital stay in Group-I $(p=0.140)$. On the other hand, in Group-2, the number of distal shots, fluoroscopy duration, effective radiation dose and operation duration were lower compared to Group-I, although this difference was not statistically significant $(p=0.057,0.073,0.058$ and 0.056 , respectively). Failure was encountered in distal locking during the first attempt in three cases in Group-I and in two cases in Group-2. Aseptic nonunion was observed in one patient in both groups.

CONCLUSION: Both the FHT distal screwing technique and the EMGS distal screwing technique are highly effective methods for distal locking. The duration of operation, the duration of the fluoroscopy and radiation exposure were similar. FHT can be preferred for distal locking in conventional intramedullary nail applications, as it is effective, easy and inexpensive.

Keywords: Distal screw locking; intramedullary nailing; radiation exposure; tibial fracture.

\section{INTRODUCTION}

Intramedullary nailing (IMN) technique is the gold standard for the treatment of closed fractures of the lower extremity long bones. For orthopedic surgeons, one of the most important problems in IMN procedures is the fixation of distal locking screws (DLS). The placement of the screws can be time-consuming and challenging due to the placement of the

Cite this article as: Aslan A, Konya MN, Gülcü A, Sargın S. Is electromagnetic guidance system superior to a free-hand technique for distal locking in intramedullary nailing of tibial fractures? A prospective comparative study. Ulus Travma Acil Cerrahi Derg 2020;26:280-286.

Address for correspondence: Anıl Gülcü, M.D.

Alladin Keykubat Üniversitesi Tıp Fakültesi, Alanya Eğitim ve Araştırma Hastanesi, 07100 Alanya, Antalya, Turkey

Tel: +90242 - 5134869 E-mail: anilgulcu@gmail.com

Ulus Travma Acil Cerrahi Derg 2020;26(2):280-286 DOI: 10.14744/tjtes.2020.94490 Submitted: 21.06.2019 Accepted: 19.01.2020 Online: 02.03.2020

Copyright 2020 Turkish Association of Trauma and Emergency Surgery 
distal lock holes. Various problems can be encountered in DLS fixation, such as prolongation of the operation time, the lock screw missing the nail, formation of stress points in the bone cortex due to repeated attempts, and radiation exposure due to recurrent fluoroscopy use. For orthopedists dealing with trauma, accurate and rapid placement of DLSs with minimal radiation exposure is crucial. The conventional approach for detecting the correct point when placing DLS involves fluoroscopic free-hand technique (FHT). However, the most important disadvantage of this method is high radiation exposure. ${ }^{[1-4]}$ Therefore, new methods are needed and new guidance systems have been developed to reduce radiation exposure. ${ }^{[5,6]} A$ variety of technological methods have been developed in the treatment of lower extremity long bone fractures with IMN, such as navigation systems, laser marking, computer-aided guiders, and mechanical systems mounted proximally or distally to reduce radiation exposure when locking screws are applied. ${ }^{[7-1 I]}$ Electromagnetic guidance system (EMGS) is one of the methods developed to solve this problem. There are different results in the literature regarding radiation dose and surgery durations with the use of EMGS in DLS application. There are studies suggesting that DLS reduces operation duration radiation exposure despite studies reporting that it does not make a difference. $[4,12]$ The current literature suggest that the EMGS is a better alternative for distal locking in the IMN procedure. ${ }^{[1,12,13]}$ However, IMNs with EMGSs have the disadvantages of requiring technical skills, having a long learning curve and being uneconomical and unpractical. ${ }^{[2,3]}$ On the other hand, inexpensive and simple FHTs, which reduce radiation exposure in distal screwing, have been described. ${ }^{[2,14]}$

In this study, we aimed to compare the results of FHT and EMGS results of the distal locking method concerning surgery duration and radiation exposure in patients who underwent osteosynthesis of tibia fractures with IMN.

\section{MATERIALS AND METHODS}

\section{Study Design}

Local Ethics Committee approval was obtained for this prospective study (B.30.2.AKÜ.0.20.05.04/06-20I3/I). The sample of the study consisted of patients who underwent IMN procedure for tibial fractures between January 2013 and January 2015 in Afyonkarahisar State Hospital, Orthopedics and Traumatology Clinics. The results of a total of 53 cases were evaluated according to the exclusion and inclusion criteria from 72 patients. The patients enrolled in this study were informed that their medical records would be used in the scientific study.

\section{Inclusion Criteria}

I- Closed tibia fracture cases according to AO/OTA classification, ${ }^{[15]} 2$ - Cases treated with closed carved IMN and underwent FHT or EMGS-assisted distal locking, 3-Patients whose data were recorded during the surgery and followed up for at least one year after the operation.

\section{Exclusion Criteria}

I-Proximal and distal femur/tibia fractures, 2-Cases with incomplete skeletal maturation, 3- Old age and osteoporotic cases, 4- Secondary operations due to any complication, 5Morbidly obese patients, 6- Patients with additional trauma affecting the postoperative mobilization were excluded from this study.

\section{Data Collection}

For the above-mentioned purposes, I- Demographic and medical information of the patients were recorded, 2- Duration of surgery and the amount of bleeding were recorded. 3-Total duration of fluoroscopy (insertion of the guidewire, confirmation of the nail placement, and distal and proximal screws) and duration of the distal locking (confirmation regarding insertion of the screws, re-insertion in case of incorrect placement), and the radiation dose emitted was measured and recorded, 4- Number of distal screw locking attempts and incorrect screw placement was recorded. 5-Complications and follow-up periods were recorded.

\section{Surgical Technique}

All surgeries were performed by three surgeons (MNK, SS, AA). All three surgeons had sufficient experience with IMN and osteosynthesis and had previously performed both of the techniques mentioned. Patients who underwent osteosynthesis with IMN were divided into two groups according to the distal locking method used. Following the antiseptic preparations, the knee was flexed to $90-100^{\circ}$ in supine position under spinal anesthesia and the tibia was prepared so that it was completely hanging down. A standard parapatellar incision was done, and closed fracture reduction was performed. The length of the nail was determined by the guidewire and the width with the reamer. IMN was performed in an antegrade and carved manner in all cases. Intraoperative rotation and alignment were calibrated according to definitions made by Krettek et al. ${ }^{[16]}$

\section{Group-1 and Distal Locking Technique}

Classic intramedullary locked nails (Tıpmed ${ }^{\circledR} \mathrm{IM} /$ tibia, Turkey) were used in this group. Distal locking screws were placed using the free hand technique, as described by Aldemir et al. ${ }^{[2]}$ Surgical techniques: I. Bone centering technique, 2. Malleolar centering technique, 3.Aspiration technique. Control methods: I. Length measurement by the guidewire, 2. Metallic sound control method. For distal locking, the drill bit was first forwarded to the most-distal hole using the bone centering and medial malleolar centering technique. With the guidewire, it was checked whether the drill bit was in the lock screw hole using length measurement with the guidewire or metallic sound control method. If the drill bit was not in place, the aspiration technique was initiated (Fig. Ia). 

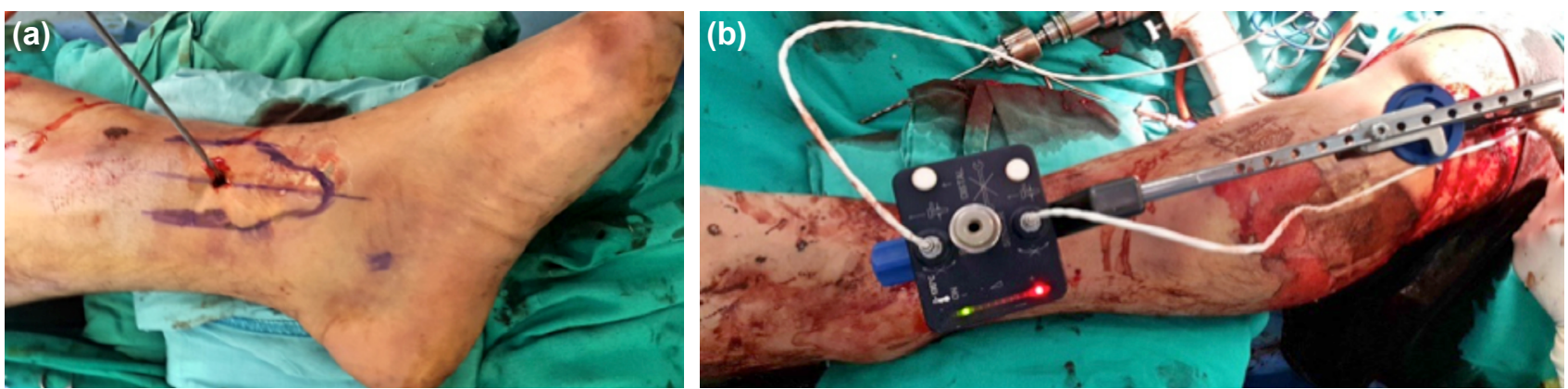

Figure 1. (a) Insertion of distal locking screws with free-hand method (FHT). (b) Insertion of distal locking screws with electromagnetic guidance (EMGS).

Group-2 and Distal Locking Technique: SpectruM ${ }^{\circledR}$ Tibia (Art Metal, Hungary) electromagnetic tibial IMN was used in this group. This nailing system consists of three parts. The first part contains the computerized control unit, the second part consists of the electromagnetic field producing handheld and the third part contains the sensory probe. Electromagnetic-assisted distal locking screws were placed with the method described in Uruç et al. ${ }^{[5]}$ (and manufacturer's manual) (Fig. Ib).

\section{Determination of Fluoroscopy Duration}

Samsung ${ }^{\circledR} 03345209$ Fluoroscopy equipment was used as a portable imaging device. After starting the distal locking, the number of fluoroscopy shots, radiation exposure measurement and locking time for all screws were compared between the two groups (Table I).

\section{Measurement of Radiation Exposure}

During the intramedullary nail application, the settings of the fluoroscopy device were set to $100 \mathrm{kVp}$ and $50 \mathrm{mAs}$. The fluoroscopy device was used by the same trained technician. The exposure dose was measured with NEB.223 RADIACMETER ${ }^{\circledR}$ obtained from the Turkish Civil Defense Directorate. A single shot of the fluoroscopy device lasted an average of two seconds and the radiation dose was 27.3 YRA. Fluoroscopy time was calculated by multiplying the total number of shots and the average shooting time $(2 \mathrm{sec})$. The operation time was calculated as minutes. Using the measurements calculated as microrad ( $\mathrm{Y}^{\mathrm{RA}}$ ) with NEB.223 RADIACMETER ${ }^{\circledR}$, the radiation dose emitted first (mGy.m2) was calculated. The effective dose (mSv) was finally calculated. Measurement of radiation exposure were calculated using the methods described in the previous studies..$^{[4,17-20]}$

\section{Statistical Analysis}

SPSS 20.0 package program was used to analyze the data. The conformity of the data to the normal distribution was checked using the Kolmogorov-Smirnov test. A chi-squared test was used to compare categorical data between the groups, and the Mann-Whitney $U$ test was used to compare mean values. $\mathrm{P}<0.05$ was considered significant.

\section{RESULTS}

The results of 56 patients were evaluated. There were 29 patients ( 10 females/ 19 males) in Group-I, of whom 17 had a fracture in the right tibia and 12 in the left tibia. In Group-2, there were 27 patients ( 9 females/ 18 males), of whom 13 had right tibia fracture and 14 had left tibia fracture. There was no statistically significant difference between the groups concerning gender and side $(p=0.928$ and $p=0.432$, respectively, Table I). The mean age in Group-I was higher than that of Group- 2 and the difference was statistically significant $(p=0,0 \mid 2$, Table I). However, there was no statistically significant difference in length of hospital stay in Group-I $(p=0.140$,

Table I. Comparison of the demographic data and clinical outcomes according to groups

\begin{tabular}{lccc}
\hline Parameter & Group I & Group II & P \\
\hline Gender (female/male) & $10 / 19$ & $9 / 18$ & 0.928 \\
Side (right/left) & $17 / 12$ & $13 / 14$ & 0.432 \\
Age (years) & $47.86 \pm 9.77$ & $39.56 \pm 13.89$ & 0.012 \\
Hospitalization (day) & $5.17 \pm 2.14$ & $4.44 \pm 1.40$ & 0.140 \\
Fluoroscopic shooting number at distal locking & $5.79 \pm 1.72$ & $4.89 \pm 1.76$ & 0.057 \\
Fluoroscopy time (sec.) & $53.17 \pm 26.56$ & $40.41 \pm 25.55$ & 0.073 \\
Operation time (min.) & $68.52 \pm 8.14$ & $64.63 \pm 6.64$ & 0.056 \\
Effective radiation (mSv) & $35.94 \pm 27.67$ & $22.69 \pm 23.15$ & 0.058 \\
\hline
\end{tabular}


Table I). On the other hand, in Group-2, the number of distal shots, fluoroscopy duration, effective radiation dose and operation duration were lower compared to Group-I, although this difference was not statistically significant $(p=0.057,0.073$, 0.058 and 0.056 , respectively, Table I).

A single shot lasted two seconds with the fluoroscopy device we used in the operating room, and the radiation dose was 27.3 uRA. Fluoroscopy duration was calculated by multiplying the total number of shots by the mean duration $(2 \mathrm{sec})$. The operation duration was calculated as minutes. Measurements were performed in $\mathrm{YRA}$ as described in the previous studies $[4,17,18]$ with the device we used; first, the radiation dose (mGy. $\mathrm{m} 2$ ) emitted to the environment was calculated, followed by the effective dose $(\mathrm{mSv})$.

\section{Complications}

Failure was encountered in distal locking during the first attempt in three cases in Group-I and in two cases in Group-2. Aseptic nonunion was observed in one patient in both groups. The revision was not performed due to rotation or extremity inequality in any case. There were no neurovascular deficits and compartment syndrome. On the other hand, in the years when this study was carried out, the cost of EM nail was twice as a conventional nail. Some of our cases from Group-I and 2 are presented in Figures 2 and 3.
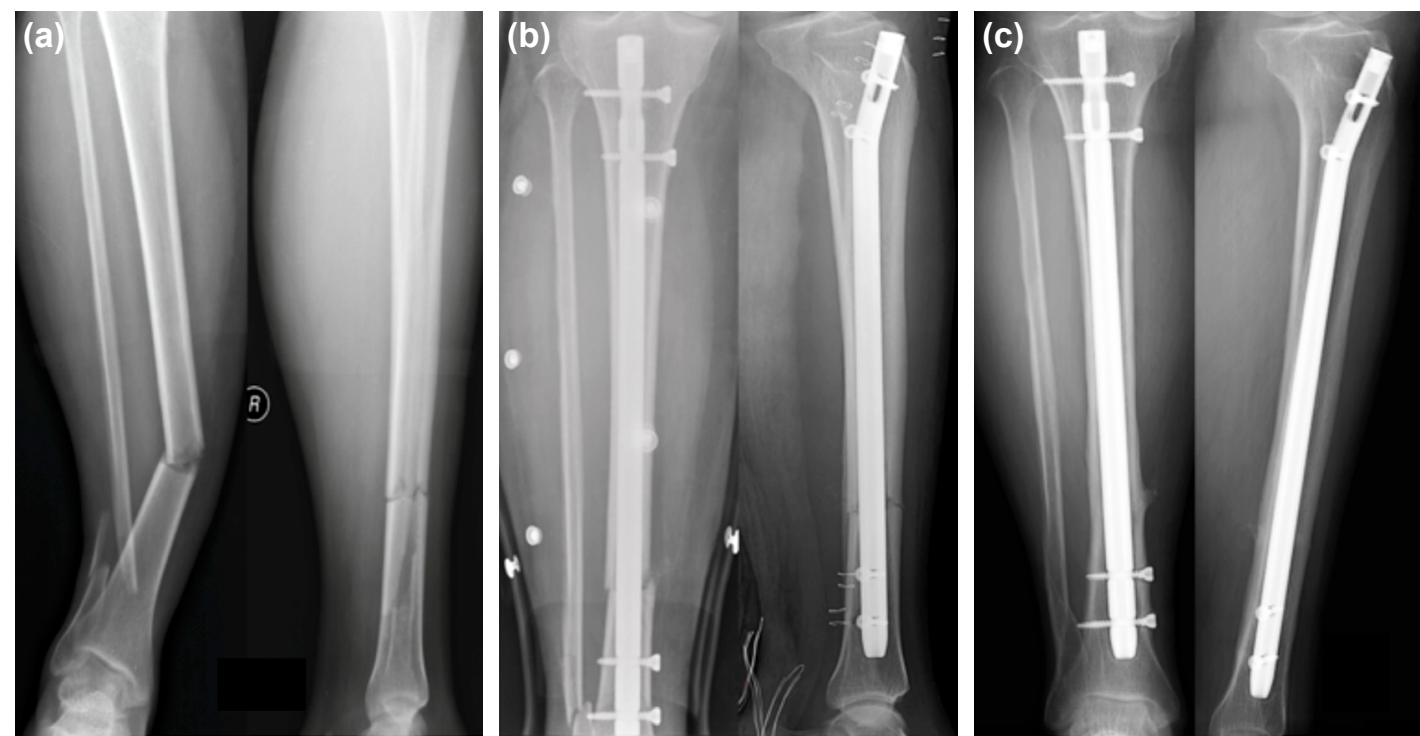

Figure 2. Preoperative anteroposterior-lateral x-ray (a), postoperative anteroposterior-lateral (b) and last follow-up anteroposterior-lateral $\mathrm{x}$-ray (c) images of a surgically treated patient, a 42 years old female, right tibia, from group 1.
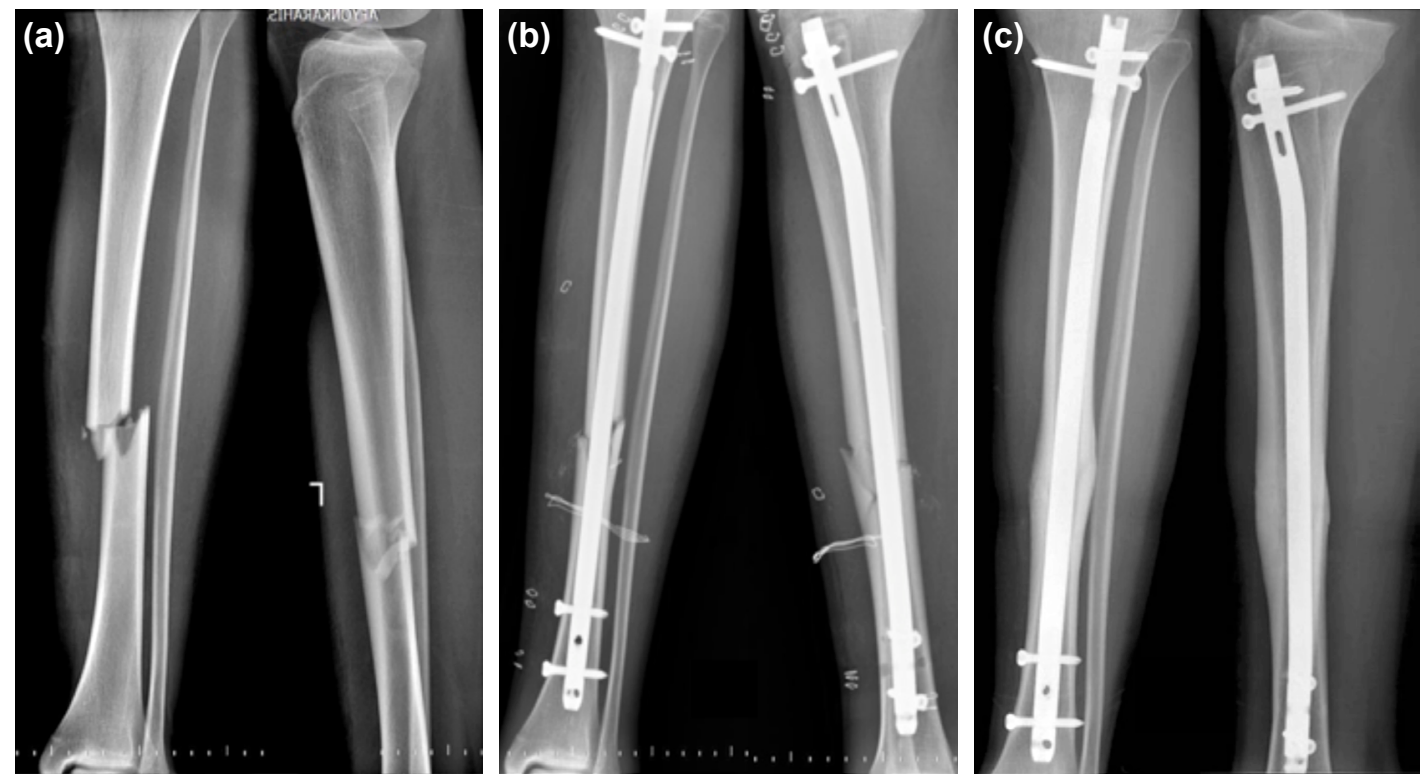

Figure 3. Preoperative anteroposterior-lateral x-ray (a), postoperative anteroposterior-lateral (b) and last follow-up anteroposterior-lateral x-ray (c) images of a surgically treated patient, a 22 years old male, left tibia, from group 2. 


\section{DISCUSSION}

Various technological methods have been developed for intramedullary nailing treatment of lower extremity long bone fractures to reduce radiation exposure when locking screws are applied: navigation systems, laser marking, computeraided guiding and mechanical systems mounted proximally or distally. ${ }^{[7-11]}$ On the other hand, many free hand techniques are known in distal screwing, as described in previous studies. ${ }^{[21]}$ In addition, inexpensive and simple methods that reduce radiation exposure and do not require fluoroscopy have also been described. ${ }^{[2,14]}$ Soni RK et al. ${ }^{[14]}$ reported that 45 of 47 tibial shaft fractures that they operated with an easy, applicable and no-radiation distal locking screw insertion technique showed complete union and no complications occurred during six months of follow-up. Aldemir et al. ${ }^{[2]}$ reported that they operated on 578 tibial fractures without using fluoroscopy with three locking techniques and two control methods, which they described with long years of experience in a very large series, and that failure in the distal locking was seen in only one patient.

In our study, patients in Group I underwent distal locking with the technique described by Aldemir et al., ${ }^{[2]}$ and we experienced failure in three of 29 cases at the first attempt. The complete union was achieved in all patients except two cases during at least one year of follow up. The difference from the studies that mentioned above may have resulted from the experience.

In long bone fractures of the lower extremities, there are studies indicating that the distal locking method with electromagnetic guidance (EMG) system does not make a difference despite studies reporting that it reduces operative time and radiation exposure. ${ }^{[4-6,12,13]}$ Studies on distal free hand and magnetic locking intramedullary nails have reported different results concerning operative time, duration of fluoroscopy and radiation exposure. Kirousis et al. ${ }^{[18]}$ reported that the mean fluoroscopy duration was $7 \mid$ seconds (19-14I) in whole intramedullary nailing procedure with free hand technique. Levin et al. ${ }^{[22]}$ reported that fluoroscopy-guided free hand-held required 60-307 seconds of fluoroscopy duration for insertion of distal locking screws. Hoffmann et al. ${ }^{[23]}$ reported that they gained 244 seconds of time with electromagnetic navigation system (without ionizing radiation) compared to the free hand fluoroscopy technique. Stathopoulos et al. ${ }^{[6]}$ reported an average distal locking time of 219 seconds (200-250) in tibial fractures using the electromagnetic-assisted computer system (SURESHOTTM). Uruc et al. ${ }^{[5]}$ reported that the electromagnetic-based targeting significantly reduced the fluoroscopy duration and operative time compared to the free hand technique. They reported that the mean operative time in the free hand group was 108 minutes, and the mean duration of the fluoroscopy was 47.77 seconds, while in the EMG group, the mean operative time was 80.96 minutes, and the mean duration of fluoroscopy was 22.59 seconds.
In our study, we could not find a significant difference concerning duration of fluoroscopy use, radiation dose and operative time in tibial fractures between electromagnetic nailing and nailing by the free-hand method, which we described.

In their free hand technique, Aldemir et al. ${ }^{[2]}$ reported failure in only one case in distal screwing. In their comparative study, Suhm et al. ${ }^{[8]}$ reported failure in one case in the group that they used the optoelectronic targeting surgical navigation system (SurgiGATE). Langfitt et al. ${ }^{[24]}$ reported that the EM-assisted system was more rapid than the free hand technique in the IMN operations of the tibia and femur fractures and resulted in fewer screw problems. Uruc et al. ${ }^{[5]}$ reported no failure of free hand technique and EM- assisted distal screwing in any of the patients. Dursun et al. ${ }^{[25]}$ reported that the magnetic locking system was as accurate as the standard hand technique for distal locking during tibial intramedullary nailing, and no failure in distal screwing was encountered in both groups.

In our study, failure was encountered at the first attempt in distal screwing in three cases in Group-I and in 2 cases in Group-2.

As discussed above, current literature suggests that the EM technique is a better alternative for distal locking in the intramedullary nailing procedure. ${ }^{[1,12,13]}$ However, devices accompanying the EMG-assisted distal screwing systems have the disadvantages of requiring technical skills, a long learning curve, and being uneconomic and unpractical. ${ }^{[2,3]}$

The results of our study showed no difference between the EMG and FHM in tibia fractures. In addition, the price of EMK nails was twice as expensive as the conventional nail at the time of our study.

In the literature, the effective dose detected during intramedullary nailing in several studies has been reported between 2.5 and 87.6 microSv. ${ }^{[18,26-30]}$

In our study, the mean effective radiation dose was 35.94 in Group-I and 22.69 in Group-2. The difference between the groups was not significant. The effective radiation doses in both groups were consistent with the literature. Moreover, when evaluated cumulatively, they were not high enough to affect human health.

\section{Strengths and Limitations of this Study}

Although there are similar comparative studies, ${ }^{[5,8,12,13]}$ the free hand technique described in the studies is different. On the other hand, the study of Aldemir et al. ${ }^{[2]}$ which we used the free hand technique's, is not comparative and it was written in Turkish. Therefore, we believe that our results regarding a simple, inexpensive, accessible technique described in our country with a comparative study will contribute to the literature. The inadequacy of the number of cases and the 
lack of homogeneous distribution among the groups can be considered as the limitations of our study.

\section{Conclusion}

Both the FHT distal screwing technique and the EMGS distal screwing technique are highly effective methods for distal locking. The duration of operation, the duration of the fluoroscopy use and radiation exposure were similar. FHT can be preferred for distal locking in conventional intramedullary nail applications, as it is effective, easy and inexpensive.

Ethics Committee Approval: Approved by the local ethics committee.

\section{Peer-review: Internally peer-reviewed.}

Authorship Contributions: Concept: A.A.; Design: A.A.; Supervision: A.A., M.N.K., S.S.; Fundings: A.A., M.N.K., S.S., A.G.; Materials: M.N.K., S.S., A.G.; Data: A.A., M.N.K., S.S.; Analysis: A.A., A.G.; Literature search: S.S., A.G.; Writing: A.A., S.S., A.G.; Critical revision: A.A., M.N.K.

Conflict of Interest: None declared.

Financial Disclosure: The authors declared that this study has received no financial support.

\section{REFERENCES}

1. Zhu Y, Chang H, Yu Y, Chen W, Liu S, Zhang Y. Meta-analysis suggests that the electromagnetic technique is better than the free-hand method for the distal locking during intramedullary nailing procedures. Int Orthop 2017;41:1041-8. [CrossRef]

2. Aldemir C, Doğan A, İnci F, Sertkaya Ö, Duygun F. Distal locking techniques without fluoroscopy in intramedullar nailing. Eklem Hastalik Cerrahisi 2014;25:64-9. [CrossRef]

3. Whatling GM, Nokes LD. Literature review of current techniques for the insertion of distal screws into intramedullary locking nails. Injury 2006;37:109-19. [CrossRef]

4. Konya MN, Kaya ÖA. Can radiation exposure be reduced in the treatment of femur fractures with the Intrameduller nail? Acta Med Alanya 2017;1:22-3. [CrossRef]

5. Uruc V, Ozden R, Dogramac1 Y, Kalac1 A, Dikmen B, Yıldız OS, et al. The comparison of freehand fluoroscopic guidance and electromagnetic navigation for distal locking of intramedullary implants. Injury 2013;44:863-6.

6. Stathopoulos I, Karampinas P, Evangelopoulos DS, Lampropoulou-Adamidou K, Vlamis J. Radiation-free distal locking of intramedullary nails: evaluation of a new electromagnetic computer-assisted guidance system. Injury 2013;44:872-5. [CrossRef]

7. Abdlslam KM, Bonnaire F. Experimental model for a new distal locking aiming device for solid intramedullary tibia nails. Injury 2003;34:363-6.

8. Suhm N, Messmer P, Zuna I, Jacob LA, Regazzoni P. Fluoroscopic guidance versus surgical navigation for distal locking of intramedullary implants. A prospective, controlled clinical study. Injury 2004;35:567-74.

9. Malek S, Phillips R, Mohsen A, Viant W, Bielby M, Sherman K. Computer assisted orthopaedic surgical system for insertion of distal locking screws in intra-medullary nails: a valid and reliable navigation system. Int J Med Robot 2005;1:34-44. [CrossRef]

10. Zirkle LG Jr, Shearer D. SIGN technique for retrograde and antegrade approaches to femur. Tech Orthop 2009;24:247-52. [CrossRef]
11. Ricci WM, Russell TA, Kahler DM, Terrill-Grisoni L, Culley P. A comparison of optical and electromagnetic computer-assisted navigation systems for fluoroscopic targeting. J Orthop Trauma 2008;22:190-4.

12. Han B, Shi Z, Fu Y, Ye Y, Jing J, Li J. Comparison of free-hand fluoroscopic guidance and electromagnetic navigation in distal locking of femoral intramedullary nails. Medicine (Baltimore) 2017;96(:e7450.

13. Moreschini O, Petrucci V, Cannata R. Insertion of distal locking screws of tibial intramedullary nails: a comparison between the free-hand technique and the SURESHOT ${ }^{\text {тm }}$ Distal Targeting System. Injury 2014;45:405-7.

14. Soni RK, Mehta SM, Awasthi B, Singh JL, Kumar A, Thakur L, et al. Radiation-free Insertion of Distal Interlocking Screw in Tibial and Femur Nailing: A Simple Technique. J Surg Tech Case Rep 2012;4:15-8.

15. Meinberg EG, Agel J, Roberts CS, Karam MD, Kellam JF. Fracture and Dislocation Classification Compendium-2018. J Orthop Trauma 2018;32 Suppl 1:S1-S170. [CrossRef]

16. Krettek C, Miclau T, Grün O, Schandelmaier P, Tscherne H. Intraoperative control of axes, rotation and length in femoral and tibial fractures. Technical note. Injury 1998;29 Suppl 3:C29-C39. [CrossRef]

17. Müller MC, Welle K, Strauss A, Naehle PC, Pennekamp PH, Weber $\mathrm{O}$, et al. Real-time dosimetry reduces radiation exposure of orthopaedic surgeons. Orthop Traumatol Surg Res 2014;100:947-51. [CrossRef]

18. Kirousis G, Delis H, Megas P, Lambiris E, Panayiotakis G. Dosimetry during intramedullary nailing of the tibia. Acta Orthop 2009;80:568-72.

19. Ehlinger M, Dillman G, Czekaj J, Adam P, Taglang G, Brinkert D, et al. Distal targeting device for long Gamma nail $\left({ }^{\circ}\right)$. Monocentric observational study. Orthop Traumatol Surg Res 2013;99:799-804. [CrossRef]

20. Lee YS, Lee HK, Cho JH, Kim HG. Analysis of radiation risk to patients from intra-operative use of the mobile X-ray system (C-arm). J Res Med Sci 2015;20:7-12.

21. Tyropoulos S, Garnavos C. A new distal targeting device for closed interlocking nailing. Injury 2001;32:732-5. [CrossRef]

22. Levin PE, Schoen RW Jr, Browner BD. Radiation exposure to the surgeon during closed interlocking intramedullary nailing. J Bone Joint Surg Am 1987;69:761-6. [CrossRef]

23. Hoffmann M, Schröder M, Lehmann W, Kammal M, Rueger JM, Herrman Ruecker A. Next generation distal locking for intramedullary nails using an electromagnetic X-ray-radiation-free real-time navigation system. J Trauma Acute Care Surg 2012;73:243-8. [CrossRef]

24. Langfitt MK, Halvorson JJ, Scott AT, Smith BP, Russell GB, Jinnah $\mathrm{RH}$, et al. Distal locking using an electromagnetic field-guided computer-based real-time system for orthopaedic trauma patients. J Orthop Trauma 2013;27:367-72. [CrossRef]

25. Dursun M, Kalkan T, Aytekin MN, Celik I, Uğurlu M. Does the magnetic-guided intramedullary nailing technique shorten operation time and radiation exposure?. Eur J Orthop Surg Traumatol 2014;24:1005-11.

26. Muzaffar TS, Imran Y, Iskandar MA, Zakaria A. Radiation exposure to the surgeon during femoral interlocking nailing under fluoroscopic imaging. Med J Malaysia 2005;60 Suppl C:26-9.

27. Blattert TR, Fill UA, Kunz E, Panzer W, Weckbach A, Regulla DF. Skill dependence of radiation exposure for the orthopaedic surgeon during interlocking nailing of long-bone shaft fractures: a clinical study. Arch Orthop Trauma Surg 2004;124:659-64. [CrossRef]

28. Fuchs M, Schmid A, Eiteljörge T, Modler M, Stürmer KM. Exposure of the surgeon to radiation during surgery. Int Orthop 1998;22:153-6.

29. Coetzee JC, van der Merwe EJ. Exposure of surgeons-in-training to radiation during intramedullary fixation of femoral shaft fractures. S Afr Med J 1992;81:312-4.

30. Kim KP, Miller DL, Berrington de Gonzalez A, Balter S, Kleinerman $\mathrm{RA}$, et al. Occupational radiation doses to operators performing fluoroscopically-guided procedures. Health Phys 2012;103:80-99. [CrossRef] 
ORİIINAL ÇALIŞMA - ÖZET

\section{Tibia kırıklarının intramedüller çivilemesinde, distal kilitleme için elektromanyetik yönlendirme sistemi, serbest el tekniğinden üstün müdür? İleriye yönelik karşılaştırmalı bir çalışma \\ Dr. Ahmet Aslan, ${ }^{1}$ Dr. Mehmet Nuri Konya, ${ }^{2}$ Dr. Anıl Gülcü, ${ }^{1}$ Dr. Serdar Sargın ${ }^{3}$}

${ }^{1}$ Alanya Alaaddin Keykubat Üniversitesi Tıp Fakültesi, Ortopedi ve Travmatoloji Anabilim Dalı, Antalya

${ }^{2}$ Afyon Sağlık Bilimleri Üniversitesi Tıp Fakültesi, Ortopedi ve Travmatoloji Anabilim Dalı, Afyonkarahisar

${ }^{3}$ Balıkesir Üniversitesi Tıp Fakültesi, Ortopedi ve Travmatoloji Anabilim Dalı, Balıkesir

AMAÇ: Intramedüller çivileme (IMÇ) tekniği, alt ekstremite uzun kemiklerinin kapalı kırıklarının tedavisinde altın standarttır. Ortopedik cerrahlar için IMÇ prosedürlerindeki en önemli sorunlardan biri distal kilitleme vidalarının (DKV) yerleştirilmesidir. DKV'ların en az radyasyona maruz kalma ile doğru ve hızlı bir şekilde yerleştirilmesi çok önemlidir. Bu çalışmada, tibia kırıklarında iMÇ ile osteosentez uygulanan hastalarda ameliyat süresi ve radyasyon maruziyeti açısından iki farkı distal kilitleme yönteminin sonuçlarını karşılaştırmayı amaçladık.

GEREÇ VE YÖNTEM: İleriye yönelik yapılan bu çalışmada toplamda 72 hastadan dahil etme ve dışlama kriterlerini karşılayan 56 olgunun sonuçları değerlendirildi. Hastalar distal vidalama yöntemine göre iki gruba ayrıldı. Grup-I ( $n=29)$ distal kilitleme için serbest el tekniği (SET) kullanılan hastaları, Grup-2 ( $n=27)$ distal kilitleme için elektromanyetik yönlendirme sistemi (EMYS) kullanılan hastaları içeriyordu. Hastaların demografik ve tıbbi bilgileri, ameliyat süreleri, kanama miktarları, toplam floroskopi süreleri, distal kilitleme için geçen süreler, maruz kalınan radyasyon dozu ölçümleri, distal vida kilitleme için teşebbüs sayıları, hatalı vida yerleşimleri, komplikasyonlar ve takip süreleri kaydedildi. Gruplar demografik veriler ve klinik sonuçlar açısından karşılaştıııldı.

BULGULAR: Gruplar arasında cinsiyet ve taraf açısından istatistiksel olarak anlamlı fark yoktu (sırasıyla, $p=0.928$ ve $p=0.432$ ). Grup I'deki yaş ortalaması Grup-2'den daha yüksekti ve fark istatistiksel olarak anlamlı idi $(p=0.012)$. Ancak, Grup-l'de hastanede kalış süresi açısından istatistiksel olarak anlamlı bir fark yoktu ( $p=0.140)$. Diğer taraftan Grup-2'de distal atım sayısı, floroskopi süresi, etkili radyasyon dozu ve operasyon süresi Grup- I'e göre daha düşüktü, ancak bu fark istatistiksel olarak anlamlı değildi (sırasıyla, $p=0.057,0.073,0.058$ ve 0.056 ). Grup- I'deki üç olguda ve Grup-2'deki iki olguda ilk denemede distal kilitlemede başarııılıkla karşılaşıldı. Her iki grupta bir hastada aseptik kaynamama gözlendi.

TARTIŞMA: Hem SET hem de EMYS distal vidalama tekniği, distal kilitleme için oldukça etkili yöntemlerdir. Ameliyat süresi, floroskopi süresi ve radyasyona maruz kalma benzerdir. Geleneksel IMÇ uygulamalarındaki distal kilitlemelerde, etkili, kolay ve ucuz olduğu için SET tercih edilebilir. Anahtar sözcükler: Distal vida kilitleme; intramedüller çivileme; radyasyon maruziyeti; tibia kırı̆̆ı.

Ulus Travma Acil Cerrahi Derg 2020;26(2):280-286 doi: 10.14744/tjtes.2020.94490 